\title{
INTERPRETER TRAINING: TAKING ACCOUNT OF INTERCULTURAL COMMUNICATION
}

\author{
Biljana Radeva \\ British Embassy Skopje \\ Biljana.Radeva2@fco.gov.uk \\ Emilija Saržoska-Georgievska \\ Ss. Cyril and Methodius University, Skopje \\ e.georgieva@flf.ukim.edu.mk
}

Communication settings involving interpreters are always instances influenced by intercultural factors, due to the fact that in interpreted communication there is the co-presence of two or more cultural and language systems which inevitably give rise to potential misunderstandings or misinterpretations of the original, intended message issued by the speaker. The point of departure of the study is the understanding that besides being language experts, interpreters also need to acquire intercultural effectiveness in order to successfully practice their profession.

The study discusses basic concepts of intercultural communication and examines the relationship between interpreting and intercultural awareness, particularly focusing on the role and specific skills of the interpreter. To this effect, a survey was carried out among professional interpreters in the Republic of Macedonia. The aim of the survey was to test interpreters' point of view of the way they perceive their role during the interpretative event. The importance of including the teaching of intercultural communication as part of the interpreter training program at the Faculty of Philology "Blaže Koneski" - Skopje, will also be highlighted.

Keywords: conference interpreting, intercultural communication, intercultural communicative competence 


\title{
ОБУКА НА КОНФЕРЕНЦИСКИ ТОЛКУВАЧИ СО АКЦЕНТ НА ИНТЕРКУЛТУРНАТА КОМУНИКАЦИЈА
}

\author{
Билјана Радева \\ Британска Амбасада Скопје \\ Biljana.Radeva2@fco.gov.uk \\ Емилија Саржоска-Георгиевска \\ Универзитет „Св. Кирил и Методиј“, Скопје \\ e.georgieva@flf.ukim.edu.mk
}

Секој процес на комуникација кој вклучува толкувачи е под влијание на интеркултурни фактори, затоа што конференциското толкување како активност ја изразува нераскинливата врска помеѓу јазикот, културата и интеркултурната комуникација. Општоприфатен еставот дека толкувачите треба да ја пополнат лингвистичката празнина во комуникацијата. Трудот укажува на тоа дека конференциските толкувачи треба успешно да ја премостат и културолошката празнина, односно да се занимаваат со културолошкиот аспект на пораката.

Трудот ја дефинира интеркултурната комуникациска компетенција (ИКК) со ставање акцент на вештините кои толкувачите треба да ги стекнат за успешно да ја извршуваат својата професија. Понатаму сепрезентираатрезултатитеод емпириското истражување, спроведено на терен во Република Македонија, кое вклучува професионални толкувачи вработени во државните институции. Се нагласува и потребата од воведување на „Интеркултурна комуникација“ како посебен курс во програмата за обука на идните толкувачи на Катедрата за англиски јазик и книжевност на Филолошкиот факултет „Блаже Конески“ - Скопје.

Клучни зборови: конференциско толкување, интеркултурна комуникација, интеркултурна комуникациска компетенција 


\section{Introduction and background of the study}

Interpreting (...) is not merely transposing from one language to another. It is, rather throwing a semantic bridge between two different cultures, two different 'thought worlds'. (Namy 1978: 25)

Cultural differences have an immediate effect on the interpreting process due to the inextricable link between language and culture. Communication settings involving interpreters (interpreter-mediated intercultural interactions) are always instances influenced by intercultural factors due to the presence of two or more cultural and language systems (Spencer-Oatey and Xing 2009: 1). There are at least three parties: the two or more (groups of) primary interlocutors who want to communicate with each other but who do not speak the same language, and the interpreter(s). During formal interpretative events, such as international conferences or diplomatic negotiations, where simultaneous or consecutive interpreting occurs, the impact that the interpreter can have on the primary interlocutors is limited, although not on the message itself. In many other situations, the interpreter's role is more flexible and $\mathrm{s} / \mathrm{he}$ is an active participant who dynamically influences the ways in which the discourse develops. Katan (quoted in Kondo et al. 1997:152) claims that interpreters should adjust their roles and become cultural mediators, particularly in business contexts. The interpreters should work with business parties before the events preparing them for any intercultural problems that might occur. They should have the right to stop proceedings if a misunderstanding is causing difficulty, and prepare materials to brief clients and raise awareness of the cultural factors in communication.

The present paper aims to demonstrate that interpreters are by necessity intercultural mediators and that by gaining intercultural competence and skills, they may prevent communication breakdown and misunderstandings from occurring. The interpreter is more than a language expert; the interpreter's role is expanding to include the intercultural plane. It is a common misconception that acquiring intercultural skills and the development of intercultural effectiveness is a practical skill which is learnt through work experience (Radeva 2014: 12).

The study will offer some general definitions of intercultural competence, focusing specifically on the kind of skills that interpreters need to develop in order to successfully practice their profession. Furthermore, the study will present the results of a survey carried out among interpreters employed in government institutions in the Republic of Macedonia. The final section of this paper will discuss what would the possible outcome of including a module of 
Intercultural Communication as part of the Interpreter Training Programme at the Postgraduate Master in Conference Interpreting at the Faculty of Philology "Blaže Koneski" - Skopje.

\section{The link between intercultural communication and interpreting}

We live in an era when intercultural encounters and conflicts are being brought to everyone's attention and when people around the world are becoming aware of the need to try to understand and to cope with the challenges that cultural encounters may cause (Lund 2008: 2).

Intercultural communication focuses on the interaction between two or more cultures that do not share the same language. Gudykunst (2000: 314), a communication studies scholar, distinguishes it from cross-cultural studies of communication as follows:

Cross-cultural and 'intercultural' are often regarded as interchangeable. They are, nevertheless different. Cross-cultural research involves comparing behavior in two or more cultures (e.g. comparing self-disclosure in Japan, USA and Iran when individuals interact with members of their own culture). Intercultural research involves examining behavior when members of two or more cultures interact (e.g. examining self-disclosure when Japanese and Iranians communicate with each other)...Understanding cross-cultural differences in behavior is a prerequisite for understanding intercultural behavior. (Gudykunst 2000: 314)

During interpreted communication - which is an instance of intercultural communication, there is the presence of two or more different cultural systems which give rise to disparities between on the one hand, the way the sender packages the message, and on the other, the receiver's expectations. The intercultural factor is considered as a source of potential barrier in the communication channel (Angelelli 2004: 2).

The interpreters' role is crucial because they are called upon to provide smooth communication between speaker and audience and to remedy the cultural noise by adapting the cultural specificities of the original to suit the audience's expectations (Kondo 1997:158).

The interpreter is an intermediary whose task is to help participants understand each other's cultural differences rather than pretend they do not exist. More precisely, interpreters should intervene only to establish understanding and communication between the participants while at the same time remaining faithful and accurate to the original speaker's message. The extent to which the interpreter intervenes is relative - depending on the knowledge the interlocutors 
have of one another and how remote their cultural and linguistic backgrounds are perceived to be (Seleskovitch 1978:114).

The translation process involved in interpreting is not a direct conversion of the source language (SL) linguistic meaning to the target language (TL); it is rather a conversion from SL discourse to cognitive sense and an expression of this sense in the TL. This process is known as deverbalization, and it is the intermediate stage between perception of the original discourse and expression of this discourse in the TL (Seleskovitch 1978: 28). Seleskovitch and Lederer (1995: 220/229f) claim that deverbalization and dealing with sense rather than individual words enable the interpreter to be faithful to both content and form of the original message in the TL. Due to the fact that sense is non-verbal and as such can be expressed in any language in many ways because it is independent of linguistic form, it allows the interpreter to formulate the message in the TL in such a way as to remain faithful to the original meaning in the SL, and at the same time adapting it to suit the expectations of the TL audience. The success of the interpreted communication, or interpretative event is also based on the shared knowledge between the interlocutors, because without this shared knowledge the words and structures of speech will fail to trigger meaning (or 'sense') in the mind of the listener (Seleskovitch 1978:146).

In order for interpreters to successfully and professionally carry out their role, they need to develop intercultural skills, more precisely, intercultural communicative competence - which as we shall see below, comprises several elements: attitudes, skills, knowledge and critical cultural awareness.

\section{Defining intercultural competence}

It is an ample problematic definition and it has been argued that the term has become 'inflated' with everyone using it for their own particular purposes (Lund 2008: 2). In the context of foreign languages education and translation and interpreting, The Routledge Encyclopaedia of Language Learning and Teaching defines intercultural competence as follows: "... the ability to interact effectively with people from cultures that we recognize as being different from our own" (Guilherme 2000: 297).

The important point is that the definition focuses on the interaction and communication aspect - that ability to communicate and interact, since intercultural competence can be easily described as knowledge about different cultures, insight into cultural phenomena, respect and understanding for the 'other'. While the interpreter has to work with all of these elements, s/ he has to develop the skills to put all of the above components to use during an interpretative event, i.e. in situations of intercultural encounters involving intercultural communication. The success of the intercultural communication 
which occurs during an interpretive event, depends most of all on the level of intercultural communicative competence possessed by the interpreter which is termed 'intercultural effectiveness'. Needless to say, for smooth communication, the possession of intercultural skills by the individuals interacting would also be a precondition.

Over the years, numerous scholars and practitioners have attempted to provide a detailed description of what kind of skills are needed to develop intercultural competence (Katan2009: 4). In Europe, the model of intercultural competence developed by Michael Byram, Professor of Education at the University of Durham, England, has been most influential and has been used as a starting point for concrete educational action and training.

Byram(1997: 73) claims that the components of intercultural competence are knowledge, skills and attitudes, complemented by the values a person holds as part of belonging to a number of social groups. These values are also representative of a person's social identities. Briefly, intercultural competence involves a balance among the following five elements:

Intercultural attitudes (savoir etre): are often described in terms of curiosity and openness, readiness to suspend disbelief about other cultures and belief about one's own. This means a willingness to relativize one's own values, beliefs and behaviors, not to assume that they are the only possible and naturally correct ones, and to be able to see how they might look from an outsider's perspective who has a different set of values, beliefs and behaviors. Interpreter trainees need to become aware of their own cultural background and their own frames of reference. A comparative perspective is needed, the training should stimulate trainees to see both their own culture and the foreign cultures from different points of view. The trainees need to be confronted with many cultures, multiple perspectives, so that they can more easily identify their own cultural identity as only one of many possible identities. M.S. Byram has termed this the ability to 'decenter', i.e. "...the ability to remove oneself from the centre of the universe" (Byram 1997:73). To achieve this, trainees need to perform in-depth learning, not surface learning. This entails independent thinking and critical reflection.

Knowledge (savoirs): of social groups and their practices in one's own and in one's interlocutor country, processes of societal and individual interaction. In other words, knowledge of social processes and illustrations of those processes and products. This includes knowledge of how other people are likely to perceive you, as well as knowledge about other people.

Skills of interpreting and relating (savoir comprendre): ability to interpret a document or event from another culture, explain it and relate it to documents from one's own. 
Skills of discovery and interaction (savoir apprendre/faire): ability to acquire new knowledge of a culture and cultural practices and the ability to operate knowledge, attitudes and skills under the constraints of real time communication and interaction.

Critical cultural awareness (savoir s'engager): an ability to evaluate critically and on the basis of explicit criteria perspectives, practices and products in one's own and other cultures and countries. The trainees need this kind of awareness to be able to question their own modes of understanding.

In short, someone with some degree of intercultural competence is someone who is able to see relationships between different cultures - both internal and external to a society - and is able to mediate, that is interpret each in terms of the other, either for themselves or for other people. It is also someone who has a critical or analytical understanding of (parts of) their own and other cultures - someone who is conscious of their own perspective, of the way in which their thinking is culturally determined, rather than believing that their understanding and perspective is natural (Byram 1997: 73).

According to Vulpe, Kealey, Protheroe and Macdonald (2000: 14), at the most general level there are nine core competency areas that an interculturally effective person (IEP) should develop as qualities. These are the following:

- $\quad$ adaptation skills;

- $\quad$ an attitude of modesty and respect;

- $\quad$ an understanding of the concept of culture;

- $\quad$ knowledge of the host country and culture;

- relationship building;

- $\quad$ self-knowledge;

- intercultural communication;

- organizational skills;

- personal and professional commitment;

Another view, regarding the knowledge dimension of intercultural competence, was proposed by the Council of Europe by Risager (2007 in Lund 2008: 3). This model is particularly relevant for the training of interpreters since it places emphasis on the ways in which trainees can obtain 'knowledge of the world' (Council of Europe 2001: 101). Risager argues that an interculturally competent person in one who knows and cares about global issues and who sees himself/ herself as a world citizen rather than a citizen of a particular nation.

The above areas of knowledge and skills are by no means exhaustive and sufficient for successful intercultural communication. There are also other skills 
and competencies which are part and parcel of intercultural communicative competence. Acquiring intercultural skills is particularly relevant for conference interpreters who operate internationally in situations of intercultural encounters. In addition to foreign language skills, being able to cope with new encounters, also requires the ability to interpret the new meanings that are being conveyed to us and to relate this new input to the understandings that we already have (Lund 2008: 3). Also, intercultural skills have to do with behaving in the appropriate and acceptable way, which means having the ability to act in a way that will not be offensive or counter-productive in the given communication situation (Corbett 2003 in Lund 2008: 3).

\section{The survey}

In order to obtain a comprehensive view of the thoughts and views of professional interpreters regarding the degree of their awareness of the importance of possessing intercultural competence and skills, a survey was carried out among experienced interpreters employed in government institutions, foreign missions and free-lance. The main aim of the survey was to gain insight into whether interpreters employed in the Republic of Macedonia are aware of the importance of acquiring intercultural skills and competence.

The investigative questions which guided the empirical research were the following:

1. Are interpreters working in the Republic of Macedonia aware of the importance of acquiring intercultural skills?

2. Whether being interculturally effective would influence the success of the interpretation? Could breaks in the communication process be prevented if the interpreter possessed intercultural awareness and skills?

3. Could the interpreter cause miscommunication to occur? Could the interpreter prevent miscommunication from occurring?

4. To what extent do interpreters in the Republic of Macedonia regard themselves to be intercultural mediators? Do they simply see themselves as language experts?

\section{Results}

The respondents were required to answer the questionnaire with a simple yes or no, with an exception of the last question, where they had to choose between two options. 33 respondents took part in the survey. The questionnaire was distributed 
electronically to 40 interpreters, of which 33 responded, which is $82.5 \%$. The age of the respondents ranged from 26 to 51 years, on average 33.6 years. Work experience of the respondents ranged from 2 to 30 years, the average was 8,8 years. Out of the 33 respondents, 10 interpreters, or $30.30 \%$ were employed in government institutions, 7 or $21.21 \%$ were employed in foreign missions and 16 or $48.48 \%$ were freelance interpreters.

Question 1: Do you believe that the interpreter is more than a language expert?

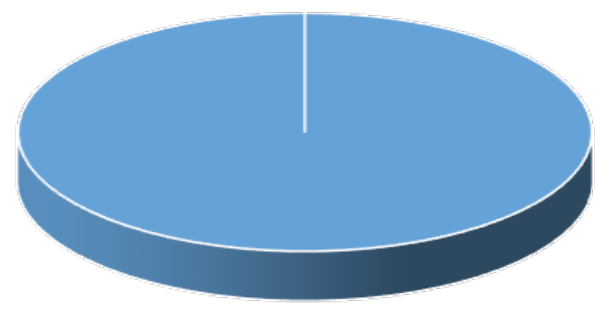

- Yes $100 \%$ No

Figure 1. Respondents' responses to Question 1

$100 \%$ of the respondents replied positively that they believe that the interpreter is more than a language expert (Figure 1).

Question 2: Are you familiar with the term Intercultural Competence?

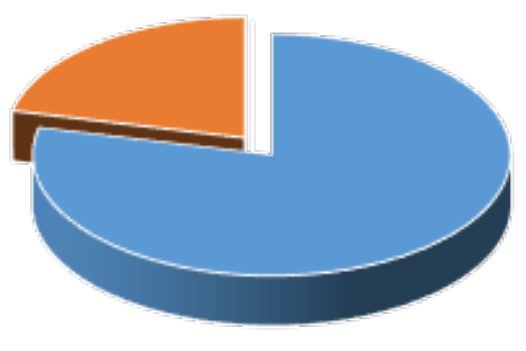

- Yes $78,78 \%$ - No $21,22 \%$

Figure 2. Respondents' responses to Question 2 
Out of 33 respondents, 26 or $78.78 \%$ replied that they are aware of the term, whereas 7 respondents or $21.21 \%$ replied negatively (Figure 2).

\section{Question 3: Haveyou undergoneany specifictraining in Intercultural Communication?}

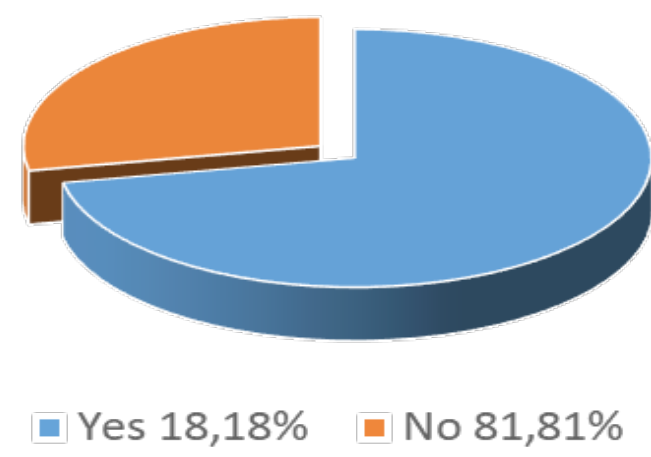

Figure 3. Respondents' responses to Question 3

Figure 3 shows that out of the total number of 33 respondents, 27 or $81.81 \%$ said that they had not gone through any kind of training in the acquisition of intercultural competence or gaining intercultural awareness. However, 6 respondents or $18.18 \%$ claimed that they had specific training in Intercultural Communication. The respondents explained that they attended informal workshops and seminars at their workplace together with all the other employees in the institution. The short seminars were not specifically tailored for the interpreters and translators. They became acquainted with the notion of intercultural communication and the competences required to practice it in various other domains, such as: human resources, public relations, business management.

The response to this question is not surprising due to the fact that the interpreters who took part in the survey have not had any formal training in conference interpreting, and during the period of their study the opportunities to obtain knowledge and skills in intercultural communication were non-existent in our country. 
Question 4: Do you think that even if the interpreter intervenes to prevent a cultural misunderstanding from occurring, s/he can still remain faithful to the meaning of the original?

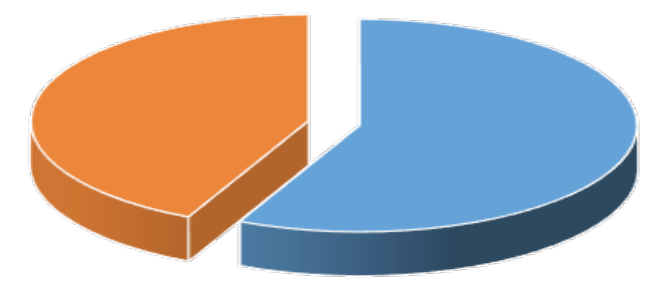

- Yes 57,01\%

- Yes to a certain extent $42,9 \%$

Figure 4. Respondents' responses to Question 4

As can be seen from Figure 4, over half of the respondents 57.1\% replied positively believing that as interpreters they can intervene to clarify cultural specificities and still remain faithful to the original message, whereas $42.9 \%$ believe that intervening might not transfer the message 'completely' correctly but 'to a certain extent'. It is interesting to note that none of the respondents believe that it is impossible to intervene when cultural disparities occur.

Question 5: Do you perceive yourself as a language expert, a cultural mediator or both cultural mediator and language expert?

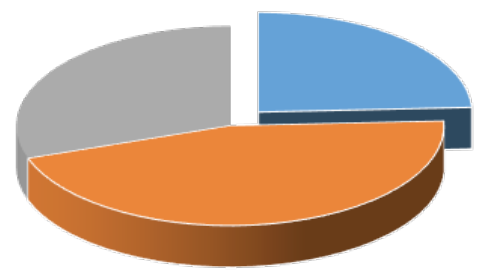

- Cultural mediator and language expert $24,24 \%$

- Language expert $45,45 \%$

- Cultural mediator $30,30 \%$

Figure 5: Respondents' responses to Question 5 
Out of the total number of respondents, 15 or $45.45 \%$ perceive themselves as language experts, 10 respondents or $30.30 \%$ see themselves as cultural mediators and 8 respondents or $24.24 \%$ regard themselves as both language experts and cultural mediators (Figure 5).

\section{Discussion and conclusion}

Trainees need to understand that interpreting, like translation, involves mediating between one or more languages and cultures. Interpreters must possess the ability to 'mindshift' from one socio-cultural reality to another. More importantly, interpreters must be trained to listen and be sensitive to the hidden meanings in the source language message, to the intentions of the speaker, and not least of all, to the possible distortions that might occur to the original message in the process of its rendering in the target language (Katan 2009: 22).

To this effect, in order to achieve the above goals, interpreters need to be able to perceive and handle difference in order to successfully communicate the source language world to the target language audience (Katan 2009: 22). This means that the development of intercultural skills involves the attainment of a substantial level of communicative awareness, which is an ongoing process and should be continuously perfected.

The research clearly demonstrated the importance of introducing a module of Intercultural Communication to interpreter training programs to sensitize trainees to intercultural challenges, enabling them to gain a greater level of communicative awareness and equipping them with intercultural competence. The crucial concept is 'intercultural competence' which is taken to be the precondition for successful intercultural communication. This means that explicit teaching in Intercultural Communication, consisting of not only lectures, but also role-plays, analyses of case-studies. This kind of instruction would enable interpreter trainees to develop an ability to identify and adapt to varying communicative conventions, or negotiate (mediate) new discourse rules in order to prevent or clarify misunderstandings. Moreover, trainees will be in a better position to use a variety of strategies (meta-communication, clarification, simplification) to prevent, solve and to mediate problems during interpreting events (Spencer-Oatey 2013: 3).

First, it would be important to analyze and understand the phenomenon of intercultural communication in itself. Second, in order for intercultural communication to be successful, the promotion and development of intercultural competence, involving the acquisition of intercultural skills and knowledge, should be supported. This in turn would empower prospective interpreter trainees to practice their profession successfully because they will be sensitized and aware of intercultural issues. 


\section{References}

Angelelli, C. (2004). Revisiting the interpreter's role: A study of conference, court, and medical interpreters in Canada, Mexico and the United States. Amsterdam and Philadelphia: John Benjamins.

Byram, M. (1997). Teaching and assessing intercultural communicative competence. Clevedon: Multilingual Matters.

Byram, M., Feng, A. and Fleming, M. (2009). Becoming interculturally competent through education and training. Clevedon: Multilingual Matters.

Byram, M. and Fleming, M. (eds.). (2003). Intercultural experience and education. Clevedon: Multilingual Matters.

Byram, M. and Neuner, G. (2003). Intercultural competence. Strasbourg: Council of Europe.

Corbett, J. (2003). An intercultural approach to English language teaching. Clevedon: Multilingual Matters.

Council of Europe. (2001). Common European framework of reference for languages. Learning, teaching, assessment. Strasbourg: Council of Europe. Retrieved from: http://www.coe.int/t/dg4/linguistic/Source/Framework_EN.pdf

Gile, D. (2009). Basic concepts and models for interpreter and translator training. Amsterdam: John Benjamins.

Gudykunst, W. B. (2000). Methodological issues in conducting theory-based crosscultural research. In H. Spencer-Oatey (ed.). Culturally speaking: Managing rapport through talk across cultures, 293-315. London: Continuum.

Gudykunst, W. B. (2005). An anxiety/uncertainty management (AUM) theory of effective communication. In W. B. Gudykunst (ed.) Theorizing about intercultural communication, 281-322. Thousand Oaks. CA: Sage.

Guilherme, M. (2000). Intercultural competence. In M. Byram (ed.). Routledge encyclopedia of language teaching and learning, 297-300. London: Routledge.

INCA (2004). Intercultural competence assessment. Retrieved from:

http://www.incaproject.org/en_downloads/2_INCA Framework Assessor version eng.pdf

Katan, D. (1999). Translating cultures: An introduction for translators, interpreters and mediators. Manchester: St. Jerome Publishing.

Katan, D. (2009). Translator training and intercultural competence. In S. Cavagnoli, E. Di Giovanni, and R. Merlini (eds.). La ricerca nella communicazione interlinguistica: Modelli teorici e metodologici, 282-301. Milan: Franco Angeli.

Kondo, M., Helen T., Alexieva, B., Dam V. H., Katan, D., Mizuno, A., Setton, R., and Zalka, I. (1997). Intercultural communication, negotiation and interpreting. In Y. Gambier, D. Gile, and C. Taylor (eds.). Conference interpreting: Current trends in research, 149-166. Amsterdam: John Benjamins.

Kotthoff, H. and Spencer-Oatey, H. (2007). Handbook of intercultural communication. Berlin: Mouton de Gruyter.

Lund, R. (2008). Intercultural competence. Acta Didactica Norge, 2 (1): 1-16.

Namy, C. (1978). Reflections on the training of simultaneous interpreters: A metalinguistic approach. In D. Gerver and W. Sinaiko (eds.). Language interpretation and communication, 25-33. New York: Plenum Press. 
Pochhaker, F. (2004). Introducing interpreting studies. London and New York: Routledge. Prechtl, E. and Davidson-Lund, A. (2007). Intercultural competence and assessment: Perspectives from the INCA project. In H. Kotthoff and H. Spencer-Oatey (eds.). Handbook of intercultural communication, 467-490. Berlin: Mouton de Gruyter.

Radeva, B. (2014). Interpreting cultures: interpreters' intercultural skills. Skopje:

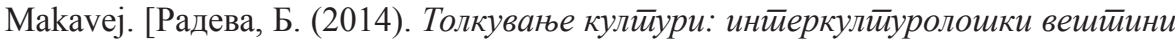
на йолкувачитее. Скопје: Макавеј.]

Risager, K. (2007). Language and culture pedagogy: From a national to a transnational paradigm. Clevedon: Multilingual Matters.

Samovar, L. A. and Porter, R. E. (1997). Intercultural communication: A reader $\left(8^{\text {th }}\right.$ edn.). Belmont, Ca: Wadsworth Publishing Company.

Seleskovitch, D. (1978). Interpreting for international conferences: Problems of language and communication. Washington D.C.: Pen and Booth.

Seleskovitch, D. and Lederer, M. (1995). A systematic approach to teaching interpretation . Silver Spring, MD: Registry of Interpreters for the Deaf.

Spencer-Oatey, H. (ed.) (2000). Culturally speaking: Managing rapport through talk across cultures. London: Continuum.

Spencer-Oatey, H. (2013). Taking account of intercultural competence. ALTE $43^{\text {rd }}$ Meeting, 17-19 April 2013. Salamanca: INCA Framework, Communicative Awareness Dimension.

Spencer-Oatey, H. and Xing, J. (1999). The impact of culture on interpreter behavior. In H. Kotthoff and H. Spencer-Oatey (eds.). Handbook of intercultural communication, 219-236. New York: Mouton de Gruyter.

Ting-Toomey, S. (1999). Communicating across cultures. New York: The Guilford Press.

Trompenaars, F. and Hampden-Turner, C. (1997). Riding the waves of culture: Understanding cultural diversity in business ( $2^{\text {nd }}$ edn.). London: Nicholas Brealy Publishing Limited.

Vulpe, T., Kealey, D., Protheroe, D. and Macdonald, D. (2000). A profile of the interculturally effective person. Ottawa, Canada: Canadian Foreign Office Institute.

Zhang, X., (2011). On interpreters' intercultural awareness. World Journal of English Language, 1(1): 47-52. 